\title{
Evaluating The Knowledge Level, Perception and Attitude Towards COVID-19 Among Otolaryngologists
}

\section{Kulak Burun Boğaz Uzmanlarının COVID-19'a Karşı Bilgi Düzeyi, Algı ve Tutumlarının Değerlendirilmesi}

\author{
Ç̧iğdem Fırat Koca \\ Malatya Turgut Özal University, Faculty of Medicine, Department of Otolaryngology Head and Neck Surgery, Malatya, Turkey
}

\begin{abstract}
Aim: Otolaryngologists cope with the COVID-19 pandemic at first lines. Inadequate knowledge level among healthcare workers may cause inadequate controlling efforts to maintain required treatments, facilitate the rapid spread of infections and an impenetrable process start.The aim of the study was to determine the attitude, knowledge level and perception of the risk of infection with COVID-19 among otolaryngologists.
\end{abstract}

Material and Method: A questionnaire consist of a total of 36 questions was prepared in order to evaluate the knowledge and attitude about COVID-19 among Otolaryngologists.

Results: The average true answer rate of knowledge questions was\% 86 (range $63-100 \%$ ) showing that a great of participants had good knowledge level about the COVID-19 in our study. The majority of the otolaryngologists showed a positive behaviour towards COVID-19.

Conclusion: According to our knowledge this present study was the first study that focused on the knowledge level and attitude towards COVID-19 among otolaryngologists.

Keywords: COVID-19, knowledge, attitude, perception, otolaryngologists
Öz

Amaç: Kulak Burun Boğaz Uzmanları, COVID-19 salgını ile ön saflarda savaşmaktadır. Sağlık çalışanları arasında yetersiz bilgi seviyesi, gerekli tedavileri sürdürmek için yetersiz kontrol çabalarına, enfeksiyonların hızlı yayılmasını kolaylaştırmaya ve aşılmaz bir sürecin başlamasına neden olabilir. Çalışmanın amacı kulak burun boğaz uzmanlarının COVID-19 enfeksiyonu riskine ilişkin tutum, bilgi düzeyi ve algısını belirlemekti.

Gereç ve Yöntem: Kulak Burun Boğaz Uzmanlarının COVID-19 hakkındaki bilgi ve tutumlarını değerlendirmek için toplam 36 sorudan oluşan bir anket hazırlandı.

Bulgular: Bilgi sorularının ortalama gerçek cevap oranı\% 86 (63-100 aralığında) olup, çalışmamızda katılımcıların büyük bir kısmının COVID-19 hakkında iyi bilgi düzeyine sahip olduğunu göstermektedir. Kulak burun boğaz uzmanlarının çoğu, COVID19'a karşı olumlu bir davranış gösterdi.

Sonuç: Bildiğimiz kadarıyla bu çalışma, Kulak Burun Boğaz Uzmanları arasında COVID-19'a yönelik bilgi düzeyi, davranış ve tutumunu inceleyen ilk çalışmadır.

Anahtar Kelimeler: COVID-19, bilgi, davranış, algı, KBB uzmanı

Corresponding (illetişim): Çiğdem Fırat KOCA, MD, Department of Otolaryngology Head and Neck Surgery, Faculty of Medicine, Malatya Turgut Özal University, Malatya, Turkey.

E-mail (E-posta): cifirat@hotmail.com

Received (Geliş Tarihi): 07.06.2021Ａccepted (Kabul Tarihi): 25.12.2021 


\section{INTRODUCTION}

On December $31^{\text {st }}, 2019$, The World Health Organization (WHO), was declared of pneumonia cases of an uncertain genesis in Wuhan, Hubei province, China. The new microorganism was defined on January 7th, 2020 as '2019 $\mathrm{n}$-CoV'. The illness caused by the virus was named given the name coronavirus disease 2019 (COVID-19) on February $11^{\text {th }}$, 2020 and on March 1 $11^{\text {th }}, 2020$ WHO defined the outbreak as a pandemic. ${ }^{[1]}$ The WHO declared many online training sessions about COVID-19 in many languages to enforce precautions, informing healthcare workers for preparedness procedures. Inadequate knowledge level among healthcare workers may cause inadequate controlling efforts to maintain required treatments, facilitate the rapid spread of infections in hospitals. ${ }^{[2]}$ Healthcare workers have an essential role in terms of combating the pandemic and have to be aware of updated testing guidelines and novel treatment modalities. There is a great deal of misinformation is spread during a pandemic, particularly due to social media. This misinformation exists even among health care professionals. ${ }^{[3]}$ It is very important for an otolaryngologist to keep himself from the disease and to fight with the disease at frontlines. ${ }^{[4]}$ The aim of the study was to determine the attitude, knowledge level and perception of COVID-19 among otolaryngologists.

\section{MATERIAL AND METHOD}

We performed this present study after approval of the Ministry of Health in Turkey and Malatya Clinical Research Ethics Committee (number 2020/176). A questionnaire consisting of a total of 36 questions that included six demographic questions, 17 COVID-19 specific knowledge questions, eight questions regarding attitude and behaviour in terms of the disease, three questions about the current literature, conference follow up, and participation, and two questions about personal care was prepared in order to analyze the knowledge of and attitude regarding COVID-19 among otolaryngologists. The general information questions were prepared using international guidelines from the World Health Organization (WHO), the Turkish Centre for Disease Control and Prevention and the Turkish Ministry of Health, among others. The demographic data consisted of; age, sex, occupational group (ENT specialist, assistant and academician), institution (state hospital, training and research hospital, university, private hospital, and other), marital status, total working years. A group of otolaryngologists analyzed the scope, feasibility and consistency of the survey which was developed in Turkish. The knowledge portion included questions regarding the transmission methods, incubation period, mortality rate, diagnosis, radiological images, and treatment modalities of COVID-19. All questions were in multiple choice format and the survey was maintained available online (through Google documents) and sent to the participants (via What's App or email). General information questions were formed as multiple choice questions and calculated as 'True $=1$ point, False $=0$ point'. Behavioural questions were also formed as multiple choice questions and calculated like 'Always equals to 5 points, Often as 4 points, Sometimes 3 points, Rarely 2 points and Never refers to 1 points'. We included the participants who accept to participitate voluntarily. A total of 102 otolaryngologists participated the questionnaire.

The data was analyzed by the SPSS "Statistical Package for Social Sciences (SPSS17.0)" program. Percentages, average, standard deviation, minimum, maximum values were calculated. In terms of the variables, KolmogorovSmirnov test statistics $(p>0.05)$ were suitable for normal distribution and parametric test statistics were used. The differentiation between the two groups was evaluated using the Independent Samples Test. The difference between more than two groups was evaluated by ANOVA test. Chisquare test was utilized to evaluate the data and compare qualitative variables. The Kolmogorov-Smirnov test statistics $(p<0.05)$, non-parametric test statistics, the Kruskal Wallis test, and Mann-Whitney $U$ were utilized for data not suitable for normal distribution. The relationship between two variables was analyzed by Pearson Correlation test. An alpha error level of $p<0.05$ was accepted as considerable in statistical comparisons.

\section{RESULTS}

\section{Demographic Features of Participants}

We obtained 102 valid responses from participants. Table 1 summarizes the characteristics of the population. The mean age was $41.4 \pm 7.05$ years. $69.6 \%$ of participants were ENT specialist, $3.9 \%$ were assistant and $26.5 \%$ were academician.

\begin{tabular}{lcc}
\hline Table 1. Demographic characteristics of participants & \\
& $\mathbf{n}$ & $\%$ \\
\hline Gender & & \\
$\quad$ Female & 67 & 65.7 \\
Male & 35 & 34.3 \\
Profession & & \\
$\quad$ Specialist & 71 & 69.6 \\
Assistant & 4 & 3.9 \\
Academician & 27 & 26.5 \\
Institution & & \\
$\quad$ State Hospital & 21 & 20.6 \\
$\quad$ University & 20 & 19.6 \\
$\quad$ Training and Research Hospital & 41 & 40.2 \\
Private & 20 & 19.6 \\
Marital Status & & \\
$\quad$ Married & 89 & 87.3 \\
$\quad$ Single & 13 & 12.7 \\
\hline
\end{tabular}

\section{Results of Knowledge Questions}

The rates of true and false answers to the knowledge questions were given in Table 2. The results showed that the participants had satisfactory overall knowledge of COVID-19. The average true answer rate of knowledge questions was $86 \%$ (63-100\%). $82 \%$ of the participants knew 
where the name of the new type of corona virus came from. $97 \%$ knew that SARS and MERS were included in the corona virus family and $100 \%$ the formal name of COVID-19. $64.7 \%$ of ENT doctors knew that SARS- CoV-2 is an envelope single stranded RNA virus and $63.7 \%$ remembered the date of 11 th March 2020 that was announced as pandemic by WHO. $87.3 \%$ of the participants knew the typical symptoms and $65.7 \%$ of them aware of the COVID-19 potential intensive care requirement ratio. A large number of participants, 91.2 $\%$, knew the mechanism by which the virus attaches to the human cell. $77.5 \%$ of the participants replied correct answer to the question regarding the definition of 'reproduction ratio'(RR). Questions about transmission routes, disease incubation period, accurate diagnosis, and the typical thorax tomography findings were answered correctly by nearly all of the participants with percentages of $99 \%, 100 \%$, and $100 \%$, respectively. $94.1 \%$ knew that COVID-19 can also be contagious during the fever-free period. $94.1 \%$ of the participants knew the drugs used in COVID-19 treatment. $89.2 \%$ of the ENT doctors knew that the surgical mask has three layers and $68.6 \%$ of otolaryngologists agreed that the most sensitive sample for COVID-19 can be obtained from bronchoalveolar lavage. There was also no statistically significance among the correct answers given to the questions and age, gender, total working years, place of employment, or profession (Table 3).

\section{Seminar/Conference/Course Participation Results}

$37.3 \%$ of female and $17.1 \%$ of male ENT doctors reported that they had attended a conference, seminar or course on COVID-19 (Table 4). A statistically significance was determined among the genders in terms of conference, course, or seminar participation. It was statistically measured that women had a higher rate of participation than men $(p<0.05)$. No numerically significance was detected regarding conference, seminar, or course attendance between the occupational groups and the institutions. The average age of otolaryngologists attending the conference was $43.6( \pm 6.9)$ and the average age of those who did not attend was 40.4 $( \pm 6.9)$. The attendance rate was higher in older physicians $(p<0.05)$. Conference participation was not differed between occupational groups and not affected from total working years, or place of employment statistically ( $p>0.05$ ) (Table 5, 6). $61.8 \%$ of the ENT doctors (63 participants) heard about COVID-19 from a bulletin and 26 of those $(25.5 \%)$ heard from social media (Table 4).

\section{Results of Attitude Questions}

$41.1 \%$ otolaryngologists answered'often' and $6.8 \%$ answered 'always' to the question 'how often do you follow up with current articles about COVID-19?'. 46\% of doctors replied 'always' and 29\% replied 'often' to the statement 'I wash my hands before patient examination' while $71.5 \%$ answered 'always' and $23.5 \%$ answered 'often' to the statement 'I wash my hands after patient examination'. $51.9 \%$ of participants confirmed that they always wash their hands both before and after patient examination while $29.4 \%$ indicated that they do this often. Most of the otolaryngologists, $83 \%$, stated that they used to wear a surgical mask during patient examination during pandemic. Conversely, 54.9\% doctors stated that they always and $24.5 \%$ of often wear N95 or derived masks while in contact with patients. $41.1 \%$ of doctors stated that they had always tried to teach the population and remind them of COVID-19 protection methods since the pandemic began; $36 \%$ of them indicated that they tried to do this often. A large portion of doctors, $86 \%$, confirmed that they had never removed their masks when they needed to speak with the patient in the policlinic.

\begin{tabular}{|c|c|c|c|c|}
\hline \multirow{2}{*}{ Questions } & \multicolumn{2}{|c|}{ True Answers } & \multicolumn{2}{|c|}{ False Answers } \\
\hline & $\mathbf{n}$ & $\%$ & $\mathbf{n}$ & $\%$ \\
\hline COVID-19 name of origin & 82 & 80.4 & 20 & 19.6 \\
\hline Which agents belong to the corona family? & 97 & 95.1 & 5 & 4.9 \\
\hline The special name of the viral agent of COVID-19 & 102 & $100.0^{* *}$ & --- & --- \\
\hline Single- stranded RNA virus & 66 & 64.7 & 36 & 35.3 \\
\hline Announcement date of the pandemic & 65 & 63.7 & 37 & 36.3 \\
\hline ICU requirement & 67 & 65.7 & 35 & 34.3 \\
\hline Not the typical COVID-19 symptom & 89 & 87.3 & 13 & 12.7 \\
\hline The way of viral cell attachment of COVID-19 & 93 & 91.2 & 9 & 8.8 \\
\hline reproduction ratio & 79 & 77.5 & 23 & 22.5 \\
\hline Main transmission way of COVID-19 & 101 & 99.0 & 1 & 1.0 \\
\hline Whether the virus is contagious in fever-free period & 96 & 94.1 & 6 & 5.9 \\
\hline Incubation period & 102 & $100.0^{* *}$ & & \\
\hline Definitive diagnosis & 99 & 97.1 & 3 & 2.9 \\
\hline Typical thorax BT sign & 102 & $100.0^{* *}$ & & \\
\hline The most sensitive sample & 70 & 68.6 & 32 & 31.4 \\
\hline Treatment protocol & 96 & 94.1 & 6 & 5.9 \\
\hline Surgical mask layers & 91 & 89.2 & 11 & 10.8 \\
\hline
\end{tabular}


About $44 \%$ of the participants stated that they always wore all the required protective equipment in accordance with the rules while examining patients; $40 \%$ of them stated that they did this often. $13 \%$ of the participants stated that they did not eat out in order to avoid COVID-19 while $38 \%$ of them reported that they often avoided it. $15 \%$ of otolaryngologists noted that, since the pandemic began, they always paid attention to their nutrition while and $38 \%$ indicated that they often paid attention to it (Table 7). Average behavioural and attitude scores were 43.1 ( \pm
Table 4. Seminar/conference/course participation rate and the source the otolaryngologists first heard about COVID-19.

\begin{tabular}{lcc} 
Seminar/conference/course & $\mathbf{n}$ & $\%$ \\
\hline Yes & 31 & 30.4 \\
No & 71 & 69.6 \\
The source they heard first about COVID-19. & & \\
Bulletin & 63 & 61.8 \\
Social media & 26 & 25.5 \\
Newspaper & 2 & 2.0 \\
Instution & 11 & 10.8 \\
Total & 102 & 100.0 \\
\hline
\end{tabular}

Table 3. True and False Answers rate of Knowledge Questions 7th -23th between ENT specialist, assistants and academicians.

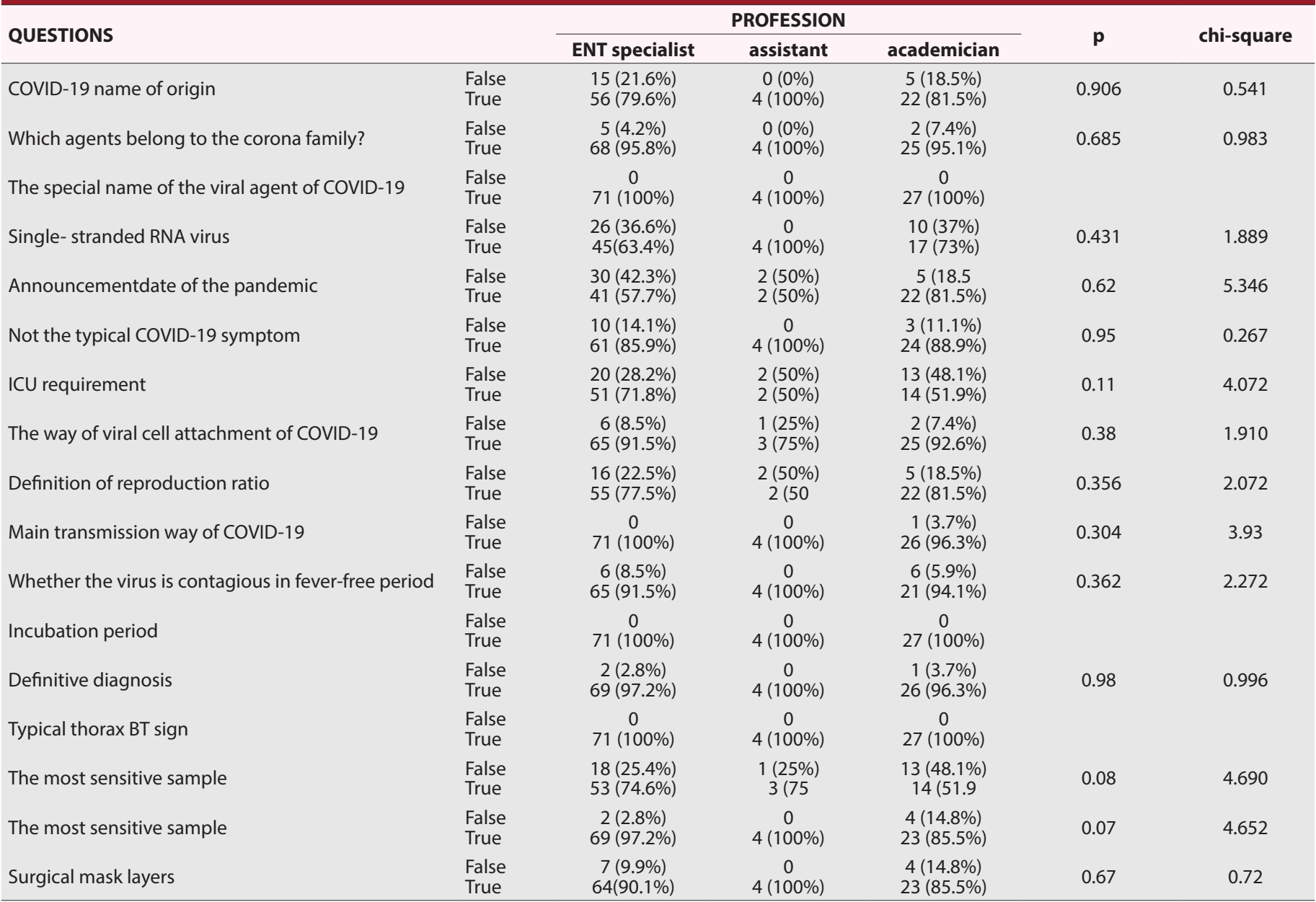

Table 5. Seminar/conference/course participation rate between ENT specialist, assistants and academicians and comparison in terms of gender and profession

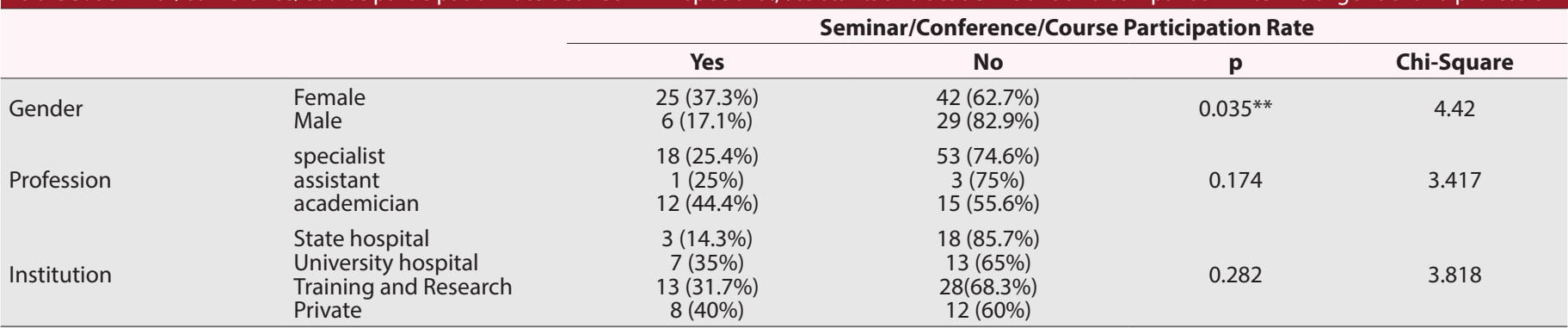


higher rate of the conference, course or seminar participation than men $(p=0.035)$. 
4) for women and 39.3 ( \pm 5.2$)$ for men. COVID-19 behaviour and attitude scores were higher among female ENT doctors than male ones. A statistically significance was detected regarding behavioural attitude score between genders $(p=0.01)$ (Table 8). A positive correlation between working year and behavioural attitude score $(r=0.269, p=0.006)$ as well as between age and behavioural attitude score was detected $(r=0.268, p=0.006)$. No statistically significant difference in COVID-19 behaviour and attitude scores existed in terms of profession or institution.

Table 6. Seminar/conference/course participation rate according to age and experience

\begin{tabular}{lccccc}
$\begin{array}{l}\text { Seminar/conference/ } \\
\text { course participation rate }\end{array}$ & $\mathbf{n}$ & $\begin{array}{c}\text { Mean } \pm \text { Std. } \\
\text { Deviation }\end{array}$ & $\mathbf{p}$ & $\mathbf{t}$ \\
\hline \multirow{2}{*}{ Age } & Yes & 31 & $43.6129 \pm 6.93627$ & & \\
& No & 71 & $40.4789 \pm 6.94233$ & $0.038^{* *}$ & 2.098 \\
Total working year & Yes & 31 & $18.1613 \pm 7.28970$ & 0.07 & 1.830 \\
& No & 71 & $15.3380 \pm 7.11125$ & & \\
\hline
\end{tabular}

** The average age of otolaryngologists attending the conference was $43.6( \pm 6.9)$, and the average age of those who did not attend was calculated as $40.4( \pm 6.9)$. The attendance rate was higher in older physicians than those who did not attend the conference. The difference was statistically significant $(p=0.038)$.

\section{DISCUSSION}

The COVID-19 microorganism was defined on January $7^{\text {th }}, 2020$ as ' $2019 \mathrm{n}$-CoV', a new coronavirus. The novel disease was named coronavirus disease 2019 (COVID-19) on February $11^{\text {th }}, 2020$ and WHO deemed the current state to be a pandemic on March 11 $11^{\text {th }}, 2020 .^{[1]} 2019-\mathrm{nCoV}$ is an enveloped single-stranded RNA virus and belongs to Coronaviridae family. S proteins help the virus to attach to the Angiotensin Converting Enzyme 2 (ACE-2) receptors of the human epithelial cells located in the respiratory mucosa. [5,6] $82 \%$ of the participants knew that the name of the new type of coronavirus came from the year it was defined and $97 \%$ of them had learned that SARS and MERS were included in the coronavirus family. $100 \%$ knew the formal name of COVID-19. 64.7\% of ENT doctors knew that SARS- CoV-2 was a kind of envelope single stranded RNA virus and $63.7 \%$ recalled the date that the pandemic was declared by WHO. Most the of participants, $91.2 \%$, knew the method by which the virus connects to a human cell.

The diagnostic tests for coronavirus are reverse-transcription polymerase chain reactions (RT-PCR), real time RT-PCRs (rRTPCT), and reverse transcription loop-mediated isothermal amplifications. Bilateral pulmonary parenchymal groundglass and consolidative pulmonary opacities, peripheral lung

Table 7. Answers of Attitude Questions between 26-36.

\begin{tabular}{|c|c|c|c|c|c|c|c|c|c|c|}
\hline \multirow{2}{*}{ Questions } & \multicolumn{2}{|c|}{ Always (n/\%) } & \multicolumn{2}{|c|}{ Often (n/\%) } & \multicolumn{2}{|c|}{ Sometimes (n/\%) } & \multicolumn{2}{|c|}{ Rarely (n/\%) } & \multicolumn{2}{|c|}{ Never (n/\%) } \\
\hline & $\mathbf{n}$ & $\%$ & $\mathbf{n}$ & $\%$ & $\mathbf{n}$ & $\%$ & $\mathbf{n}$ & $\%$ & $\mathbf{n}$ & $\%$ \\
\hline Hand washing before patient examination & 47 & 46 & 30 & 29.4 & 14 & 13.7 & 6 & 5 & 5 & 3.9 \\
\hline Follow up current articles & 7 & 6.8 & 42 & 41.1 & 39 & 38.2 & 11 & 10.7 & 3 & 2.9 \\
\hline Hand washing after patient examination & 73 & 71.5 & 24 & 23.5 & 3 & 2.9 & 2 & 1.9 & 0 & 0 \\
\hline Hand washing before and after patient examination & 53 & 51.9 & 30 & 29.4 & 9 & 8.8 & 9 & 8.8 & 1 & 0.9 \\
\hline Wearing surgical mask & 85 & 83.3 & 4 & 3.9 & 4 & 3.9 & 5 & 4.9 & 4 & 3.9 \\
\hline Wearing N95 mask & 56 & 54.9 & 25 & 24.5 & 15 & 14.7 & 6 & 5.8 & 0 & 0 \\
\hline Effort to teach around & 42 & 41.1 & 37 & 36.2 & 19 & 18.6 & 3 & 2.9 & 1 & 0.9 \\
\hline Removing mask while speaking requirement & 0 & 0 & 0 & 0 & 2 & 1.9 & 12 & 11.7 & 88 & 86.2 \\
\hline Wearing total protective equipments & 45 & 44.1 & 41 & 40.1 & 8 & 7.8 & 5 & 4.9 & 2 & 1.9 \\
\hline Not eat out & 14 & 13.7 & 39 & 38.2 & 27 & 26.4 & 15 & 14.7 & 7 & 6.8 \\
\hline Taking attention to own nutrition & 16 & 15.6 & 39 & 38.2 & 26 & 25.4 & 17 & 16.6 & 4 & 3.9 \\
\hline
\end{tabular}

Table 8. Attitude scores between groups

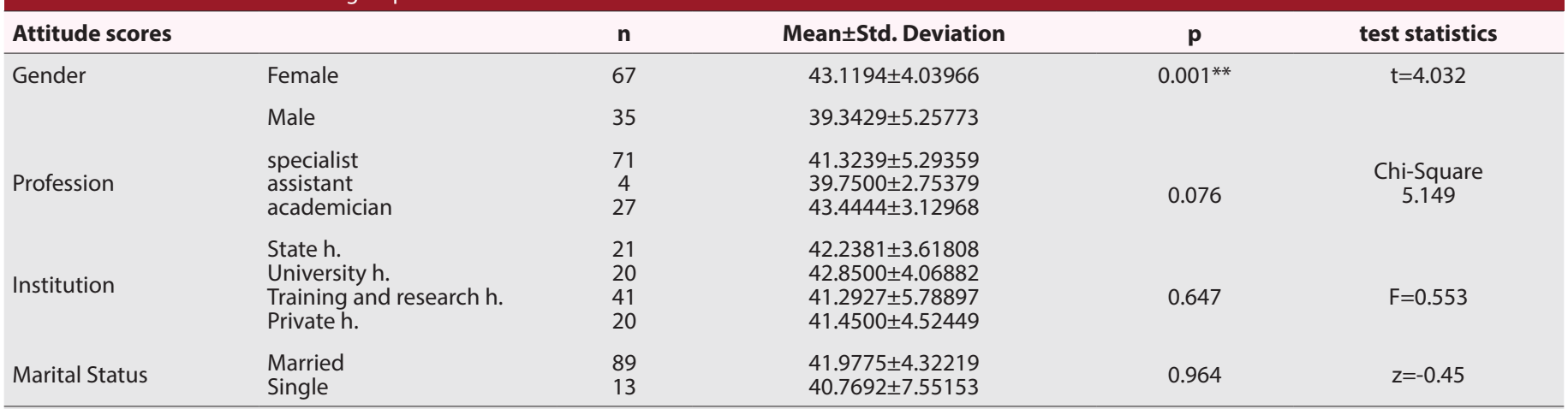

** COVID-19 behaviour and attitude scores were higher among ENT female doctors than male doctors $(p=0,001)$. 
distribution form typical CT findings of the disease. ${ }^{[7]}$ Questions about transmission ways, incubation period of the disease, definitive diagnosis, and the specific thorax tomography images of COVID-19 were answered correctly by nearly total of the participants. Fever, cough, and dispnea are the main early COVID-19 symptoms that have been clearly declared by CDC..$^{[8]}$

A vast majority of the doctors, $94.1 \%$, were aware that COVID-19 can also be contagious during the fever-free period. It has been reported in many studies that intensive care reqirement in COVID- 19 cases varies between 5-8\%.99-14] $65.7 \%$ of the otolaryngologists knew the average COVID-19 potential intensive care requirement ratio. The question about the definition of the term 'reproduction ratio' of the disease (RR) was relatively requiring detailed information and $77.5 \%$ of the participants gave the correct answer to this question. The reproduction ratio (RR) can be determined as the estimated number of patients infected through only one infected case in the whole population. ${ }^{[15]}$ Lopinavir inhibits the protease activity of the coronavirus LPV/Ritonavir combination in SARS patients, was effective as initial treatment, and is belived to reduce the death rate. Remdesivir is another antiviral agent used for COVID-19 and is considered to improve pulmonary mechanism, reduce viral loads, and cure serious pulmonary involvement. Chloroquine is an antimalarial and autoimmune disease drug. It is considered as to prevent virus reproduction through rising endosomal $\mathrm{PH}$ and has been used in the prevention and treatment of COVID-19 pneumonia. Hydroxychloroquine is a more potent chloroquine analogue in COVID-19 treatment ${ }^{[7]}$ Azitromycin is a macrolid antibiotic used in COVID-19 treatment for its features such as in-vitro decreased viral replication, blocking entrance into host cells, and immunomodulating. ${ }^{[16]}$ It is a part of COVID 19 treatment protocol of children in Turkey. Favipravir is an RNA-dependent RNA polymerase inhibitor used in COVID-19 treatment. ${ }^{[17]}$ $94.1 \%$ of the participants correctly selected the drug not included in the treatment of COVID-19.

Face masks have a preserver layer to prevent the transmission of the virus.It is important to know how to wear a face mask and how to dispose of it. A surgical mask has three layers. ${ }^{[18]} 89.2 \%$ of the ENT doctors knew this. Wenling Wang et al. detected SARS-CoV-2 in different types of clinical specimens and they indicated that bronchoalveolar lavage samples presented the highest positivity (93\%). ${ }^{[19]} 68.6 \%$ of otolaryngologists agreed that the most sensitive sample in terms of positive COVID-19 results can be gained from bronchoalveolar lavage. We could not detect a numerically significance between the otolaryngologists, residents, or assistants in terms of rates of correct answers to the questions. The average true answer rate of knowledge questions was $86 \%$ (63-100\%), showing that a great of otolaryngologists had a good knowledge level regarding COVID-19; this result was similar to those of the studies carried out by Maheshwari and Giao among medical students and healthcare workers, respectively. ${ }^{[20,21]}$ Studies about knowledge and attitude regarding COVID-19 among otolaryngologists are limited.
Sameer Mehrotra and et al. showed that $65 \%$ healthcare professionals had a moderate and another $33 \%$ of healthcare professionals had a low level of COVID-19 knowledge in their study. Maheshwari et al. found that $86 \%$ of medical students had a good level of knowledge on COVID-19 while Giao et al. found that $81 \%$ of healthcare workers had sufficient knowledge. This difference may be due to the format of the questions, yes/no or multiple choice. It is very important for doctors to have adequate knowledge about COVID-19 so that they can treat it at all phases including symptomatology, diagnosis, treatment and disease protection. Modi et al. found that their participants had an inadequate level of knowledge regarding the potential consequences of close contact. $^{[3,21,22]}$

Wahed et al. detected that direct contact to COVID-19 positive cases increased knowledge level exponentially, as dealing directly with patients allows for healthcare workers to learn more about the disease and force to read more about current literature and guidelines. ${ }^{[6]}$ Haridi et al. showed that the dental healthcare workers did not have satisfactory information regarding mandatory precautions against the infectious diseases or their transmission. Quadri et al. found that the knowledge of COVID-19 among the dental interns, dental auxiliaries, and dental specialists in Saudi Arabia is adequate. ${ }^{[8]}$

Naseer Ahmed et al. found the current knowledge level and awareness of healthcare professionals to adequate in their study. They found that healthcare professionals (HCPs) learned information about COVID-19 from multiple media sources; Sun et al. concurred. The major information source in this study was bulletins, with social media acting as a secondary resource. Naseer Ahmed et al. underlined the importance of the reliability and authenticity of the readily available COVID-19 information. Continuing education programmes such as seminars, webinars, and courses as well as constant updating of prevention methods, transmission methods, and treatment modalities should be mandatory for HCPs. ${ }^{[23]}$

ENT specialists face a high risk of infection due to their compulsory close contact to patients' upper respiratory system and the type of the procedures they carry out; this is particularly important for aerosol-generating procedures. On April 19 $9^{\text {th }}, 2020$, The Guardian headlined the death of an otolaryngology consultant from COVID-19. This was one of the first frontline hospital workers to pass away from COVID-19 in the UK. ${ }^{[1]}$

Zhang et al.found that $89 \%$ of healthcare workers had good knowledge about COVID-19. ${ }^{[24]}$ Bhagavathula et al. found that health care workers have insufficient knowledge about COVID-19 transmission prevention in their study. ${ }^{[2]}$ Public health administrators all around the world, take precautions against the pandemic and disseminated informative videos, instructive brochures, educational newsletters to increase knowledge level of the health care practitioners and general population. It is very important to wash hands appropriately and to use personal protective equipments including surgical 
masks, gloves, eye shields, etc. A well-informed health care professional is very important not only for community but also for work colleagues and patients. ${ }^{[8]}$

COVID-19 behaviour and attitude scores were higher among female ENT doctors than male ones $(p=0.01)$. a positive correlation was detected between working year and behavioural attitude score $(r=0.269 \mathrm{p}=0.006)$ and also between age and behavioural attitude score $(r=0.268, p=$ 0.006 ) in our study. Otolaryngologists are not included in the Scientific Board Established by Ministry of Health in Turkey yet. However, the opinions of otolaryngologists will be needed for the duration of the COVID-19 pandemic. It is critical for them to be able to give correct information to their communities, colleagues, and patients. Many otolaryngologists in our country have had to treat COVID-19 patients as well as their own ENT patients. They have had to educate themselves on this issue as much as infection specialists or lung and chest disease specialists directly associated with COVID-19 have; otolaryngologists should be familiar with the most recent information about COVID-19.

\section{Limitations}

However, there are some limitations in this study. Our study group was small and may be supported by large groups in future studies. Having two separate groups in the study would have made it more valuable in terms of comparing the study data, being a single-group study is a disadvantage. The questionnaire we used is self-reported and depends on the participant's honesty and recall ability in part; in this respect this may recall bias.

\section{CONCLUSION}

The knowledge and attitude scores were high among otolaryngologists in this study. To our knowledge, it was the first to focuse on the knowledge level and attitude towards COVID-19 among otolaryngologists.

\section{ETHICAL DECLARATIONS}

Ethics Committee Approval: We performed this present study after approval of the Ministry of Health in Turkey and Malatya Clinical Research Ethics Committee (number 2020/176).

Informed Consent: The first question at the beginning of the survey was asked to the participants whether they participated in our study and online survey or not. Candidates who answered the questionnaire after reading the preliminary explanation of the study and choosing the statement as I agree to participate the study and fill in the questionnaire were included in the study. Informed consent was obtained from all participants.

Referee Evaluation Process: Externally peer-reviewed. Conflict of Interest Statement: The authors have no conflicts of interest to declare.
Financial Disclosure: The authors declared that this study has received no financial support.

Author Contributions: All of the authors declare that they have all participated in the design, execution, and analysis of the paper, and that they have approved the final version.

\section{REFERENCES}

1. Banerjee S, Sarkar S, Bandyopadhyay SN. Survey and analysis of knowledge, attitude and practice among otolaryngologists in a state in eastern India in relation to the coronavirus disease 2019 pandemic. J Laryngol Otol 2020;134(8):696-702.

2. Bhagavathula AS, Aldhaleei WA, Rahmani J, Mahabadi MA, Bandari DK. Knowledge and Perceptions of COVID-19 Among Health Care Workers:Cross-Sectional Study. JMIR Public Health Surveill 2020;30(2):19160.

3. Mehrotra S, Jambunathan P, Jindal M, Gupta A, Kapoor K. A crosssectional survey to assess the knowledge regarding coronavirus disease (COVID-19) among health care professionals. Med J Armed Forces India 2020;15.

4. Kanaparthi A, Dukkireddy D, Gopalaiah H, Kesary SPR, Katne T, Gantala R. Awareness of COVID 19 pandemic among dental practioners of Telangana state, India:A cross sectional survey. J Oral Biol Craniofac Res 2020;10(4):484-9.

5. Ikhlaq A, Bint-E-Riaz H, Bashir I, ljaz F. Awareness and Attitude of Undergraduate Medical Students towards 2019-novel Corona virus Pak J Med Sci 2020;36 (COVID19-S4):32-36.

6. Abdel Wahed WY, Hefzy EM, Ahmed MI, Hamed NS. Assessment of Knowledge, Attitudes, and Perception of Health Care Workers Regarding COVID-19, A Cross-Sectional Study from Egypt J Community Health 2020;7:1-10.

7. Zhai $P$, Ding Y, Wu X, Long J, Zhong Y, Li Y. The epidemiology, diagnosis and treatment of COVID-19. Int J Antimicrob Agents 2020;55(5):105955.

8. Quadri MFA, Jafer MA, Alqahtani AS, et al. Novel corona virus disease (COVID-19) awareness among the dental interns, dental auxiliaries and dental specialists in Saudi Arabia:A nationwide study. J Infect Public Health 2020;13(6):856-64.

9. Yang $X, Y u Y, X u J$, et al. Clinical course and outcomes of critically ill patients with SARS-CoV-2 pneumonia in Wuhan, China:a single-centered, retrospective, observational study. Lancet Respir Med. 2020;8(5):475-81.

10. Wang D, Hu B, Hu C, et al. Clinical Characteristics of 138 Hospitalized Patients With 2019 Novel Coronavirus-Infected Pneumonia in Wuhan, China. JAMA 2020;323:1061.

11. Wu Z, McGoogan JM. Characteristics of and Important Lessons From the Coronavirus Disease 2019 (COVID-19) Outbreak in China:Summary of a Report of 72314 Cases From the Chinese Center for Disease Control and Prevention. JAMA 2020;323:1239.

12. Guan WJ, Ni ZY, Hu Y, et al. Clinical Characteristics of Coronavirus Disease 2019 in China. N Engl J Med 2020;382:1708.

13. Grasselli G, Pesenti A, Cecconi M. Critical Care Utilization for the COVID-19 Outbreak in Lombardy, Italy:Early Experience and Forecast During an Emergency Response. JAMA 2020;323:1545.

14. Livingston E, Bucher K. Coronavirus Disease 2019 (COVID-19) in Italy. JAMA 2020;323:1335.

15. Hamza MS, Badary OA, Elmazar MM. Cross-Sectional Study on Awareness and Knowledge of COVID-19 Among Senior pharmacy Students. J Community Health 2020;15:1-8.

16. Arshad S, Kilgore P, Chaudhry ZS et al. Treatment with hydroxychloroquine, azithromycin, and combination in patients hospitalized with COVID-19. Int J Infect Dis 2020;97:396-403.

17. Irie K, Nakagawa A, Fujita $H$, et al. Pharmacokinetics of Favipiravir in Critically III Patients With COVID-19. Clin Transl Sci 2020;13(5):880-5.

18. Kumar J, Katto MS, Siddiqui AA, et al. Knowledge, Attitude, and Practices of Healthcare Workers Regarding the Use of Face Mask to Limit the Spread of the New Coronavirus Disease (COVID-19).Cureus 2020;20,12(4):7737. 
19. Wang W, Xu Y, Gao R, et al. Detection of SARS-CoV-2 in Different Types of Clinical Specimens. JAMA 2020;12,323(18):1843-4.

20. Maheshwari S, Gupta P.K, Sinha R, Rawat P. Knowledge, attitude, and practice towards coronavirus disease 2019 (COVID-19) among medical students:a cross-sectional study. J Acute Dis 2020;9(3):100.

21. Giao H, Han NT, Van Khanh T, Ngan V.K, Van Tam V, Le An P. Knowledge and attitude toward COVID-19 among healthcare workers at district 2 Hospital, Ho Chi Minh city. Asian Pac J Trop Med 2020;13.

22. Modi PD, Nair G, Uppe A, Modi J, et al. Cureus. COVID-19 Awareness Among Healthcare Students and Professionals in Mumbai Metropolitan Region:A Questionnaire-Based Survey. 2020;2;12(4):e7514.

23. Ahmed N, Shakoor M, Vohra F, Abduljabbar T, Mariam Q, Rehman MA. Knowledge, Awareness and Practice of Health care Professionals amid SARS-CoV-2, Corona Virus Disease Outbreak. Pak J Med Sci 2020;36(COVID19-S4):49-56.

24.Zhang M, Zhou M, Tang F, et al. Knowledge, attitude and practice regarding COVID-19 among healthcare workers in Henan, China. J Hosp Infect 2020;105:183-7. 